\title{
Effects of anticonvulsants and inactivity on bone disease in epileptics
}

\author{
LiLIAN E. MURCHISON \\ P. D. BEWSHER \\ Ph.D., M.R.C.P. \\ M.D., M.R.C.P. \\ Marion Chesters \\ Ph.D. \\ Department of Therapeutics and Clinical Pharmacology, University of Aberdeen \\ J. GiLBeRT \\ B.Sc., Ph.D. \\ Department of Pharmacology, \\ University of Aberdeen \\ ELIZABETH LAW
B.Sc., M.B. \\ G. Catto \\ M.R.C.P. \\ Department of Medicine, \\ University of Aberdeen \\ E. McKAY
M.D., F.R.C.P. \\ H. S. Ross \\ M.R.C.Psych. \\ Department of Mental Health, University of Aberdeen
}

\begin{abstract}
Summary
No significant biochemical or radiological features of vitamin D deficiency were found in groups of juvenile and adult epileptics and control groups of nonepileptic patients in hospitals for the mentally retarded. There was evidence of hepatic enzyme induction in patients on anticonvulsants, in that urinary D-glucaric acid concentration and excretion were raised. No effect was found of prolonged anticonvulsant therapy on bone densitometry, but in children immobility was closely associated with decreased bone density. The evidence suggests that disuse osteoporosis is the major bone disease in these mentally retarded children.

\section{Introduction}

Recent reports have indicated that disorders of calcium metabolism may occur in patients treated with anticonvulsants. Hypocalcaemia, elevation of the serum alkaline phosphatase, and rickets and osteomalacia have been described (Dent et al., 1970; Richens and Rowe, 1970). It has been suggested that these disorders result from accelerated conversion of vitamin $\mathrm{D}$ and its more active metabolite 25-hydroxycholecalciferol to polar metabolites by drug-induced liver microsomal enzymes (Hahn et al., 1972).

The following study was prompted by the occurrence over a 4-month period of spontaneous fractures

Correspondence: Dr Lilian E. Murchison, Department of Therapeutics and Clinical Pharmacology, University Medical Buildings, Foresterhill, Aberdeen AB9 22D.
\end{abstract}

in three epileptic children in an institution for the mentally retarded. These children were severely retarded and non-ambulant, and had radiological evidence of skeletal decalcification. There were, however, no radiological signs of rickets, and only one had hypocalcaemia. The study was therefore designed to investigate the possible effects of both anticonvulsant therapy and prolonged immobility on calcium metabolism and bone density.

\section{Patients and methods}

Twenty-four children from the hospital were studied, parental consent having been obtained and the project approved by the local ethical committee. In order to determine possible separate or additive effects of anticonvulsant therapy and immobility, subjects were divided into four groups. Six ambulant and six non-ambulant epileptic children on anticonvulsant therapy were matched for age and sex with six ambulant and six non-ambulant nonepileptic children with no drug therapy. The age range was 5-19 years, and the mean age of the epileptic children was $13.3 \pm 1.2$ years and that of the controls $14.0 \pm 0.8$ years. All the epileptic children had had continuous anticonvulsant therapy for at least 2 years. Three had one anticonvulsant only, and the rest had multiple drug therapy.

As an extension of the study, four similar groups of adults from another hospital for the mentally retarded were also investigated. There were equal numbers of males and females in each group. The 
mean age of the epileptic patients was $37 \cdot 0 \pm 2 \cdot 8$ years (range 25-61 years) and that of the controls $36.3 \pm 1.9$ years (range 25-44 years). Two of the epileptics were receiving phenobarbitone only, and the remainder had multiple drug therapy.

The following investigations were carried out on a fasting blood sample obtained without venous occlusion: serum total calcium; inorganic phosphorus; alkaline phosphatase; ionic calcium using a flow-through calcium-selective electrode (Orion); serum albumin and total protein (by the Biuret method). Urinary D-glucaric acid (Hunter et al., 1971) (using glucaro-1, 4-lactone standards) and creatinine estimations were determined on early morning urine specimens from the children, and on 24-hr urine collections from the adults.

The bone mineral content of the distal third of the radius was assessed by $\gamma$-ray densitometry (Cameron and Sorenson, 1963) in all subjects, and the results calculated as a percentage of the predicted normal for each subject using tables prepared at the University of Wisconsin (Cameron, 1970). In the children shown to have bone densitometry readings $30 \%$ or more below the predicted norm, further densitometry measurements were carried out at monthly intervals during daily supplementation with $900 \mathrm{iu}$ vitamin D. Radiographs of the wrist and distal half of the radius only were taken in the children, while in the adults the pelvic and shoulder girdles were also X-rayed.

Although neither children nor adults were on a fixed dietary intake, an assessment was made of the average daily vitamin D content of the food supplied to the patients in both hospitals.

\section{Results}

No significant differences were found between epileptics and controls in serum total calcium, ionic calcium, inorganic phosphorus, or alkaline phosphatase levels (Table 1), nor were these parameters influenced by whether or not the subjects were ambulant. Low serum total calcium levels (between 9.0 and $9.6 \mathrm{mg} / 100 \mathrm{ml}$ ) were found in five epileptic children and six controls (one adult) but these were associated with a low ionic calcium level in only two controls. Serum albumin and total protein values were normal in all subjects.

The urinary glucaric acid excretion (Table 2) was significantly higher in epileptics than in controls, whether expressed as glucaric acid concentration, or 24-hr excretion, or as the glucaric acid/creatinine ratio. Although the urine creatinine concentrations

TABLE 1. Serum biochemical values (mean and s.e. mean.)

\begin{tabular}{|c|c|c|c|c|}
\hline & \multicolumn{2}{|c|}{ Epileptic } & \multicolumn{2}{|c|}{ Control } \\
\hline & Ambulant & Non-ambulant & Ambulant & Non-ambulant \\
\hline $\begin{array}{l}\text { Total calcium } \mathrm{mg} / 100 \mathrm{ml} \\
\text { children } \\
\text { adults } \\
\text { Ionic calcium } \mathrm{mg} / 100 \mathrm{ml}\end{array}$ & $\begin{array}{c}9 \cdot 6 \pm 0 \cdot 1 \\
10 \cdot 0 \pm 0.02\end{array}$ & $\begin{array}{l}9 \cdot 8 \pm 0 \cdot 2 \\
9 \cdot 9 \pm 0 \cdot 1\end{array}$ & $\begin{array}{r}9 \cdot 7 \pm 0 \cdot 2 \\
10 \cdot 0 \pm 0 \cdot 1\end{array}$ & $\begin{array}{l}9 \cdot 8 \pm 0 \cdot 1 \\
9.9 \pm 0.1\end{array}$ \\
\hline $\begin{array}{l}\text { IOnic calcium } \mathrm{mg} / 100 \mathrm{ml} \\
\text { children } \\
\text { adults } \\
\text { Inorganic phosphate } \mathrm{mg} / 100 \mathrm{ml}\end{array}$ & $\begin{array}{l}4 \cdot 9 \pm 0 \cdot 3 \\
4 \cdot 5 \pm 0 \cdot 2\end{array}$ & $\begin{array}{l}4 \cdot 9 \pm 0 \cdot 4 \\
4 \cdot 3 \pm 0 \cdot 2\end{array}$ & $\begin{array}{l}4 \cdot 5 \pm 0 \cdot 3 \\
4 \cdot 5 \pm 0 \cdot 2\end{array}$ & $\begin{array}{l}4 \cdot 7 \pm 0 \cdot 3 \\
4 \cdot 7 \pm 0 \cdot 2\end{array}$ \\
\hline $\begin{array}{l}\text { children } \\
\text { adults } \\
\text { Alkaline phosphatase K.A. units }\end{array}$ & $\begin{array}{l}4 \cdot 9 \pm 0 \cdot 1 \\
2 \cdot 9 \pm 0 \cdot 1\end{array}$ & $\begin{array}{l}4 \cdot 9 \pm 0 \cdot 3 \\
3 \cdot 0 \pm 0 \cdot 4\end{array}$ & $\begin{array}{l}4 \cdot 6 \pm 0 \cdot 3 \\
3 \cdot 2 \pm 0 \cdot 2\end{array}$ & $\begin{array}{l}4 \cdot 8 \pm 0 \cdot 3 \\
3 \cdot 0 \pm 0 \cdot 3\end{array}$ \\
\hline $\begin{array}{l}\text { children } \\
\text { adults }\end{array}$ & $\begin{array}{r}19 \cdot 0 \pm 3 \cdot 8 \\
6 \cdot 8 \pm 1 \cdot 1\end{array}$ & $\begin{array}{r}22 \cdot 6 \pm 3 \cdot 1 \\
8 \cdot 1 \pm 1 \cdot 2\end{array}$ & $\begin{aligned} 16.7 & \pm 3 \cdot 5 \\
6 \cdot 1 & \pm 0.8\end{aligned}$ & $\begin{aligned} 15 \cdot 1 & \pm 2 \cdot 5 \\
5 \cdot 0 & \pm 0.8\end{aligned}$ \\
\hline
\end{tabular}

TABLE 2. Urine glucaric acid values (mean and s.e. mean.)

\begin{tabular}{|c|c|c|c|c|c|c|}
\hline & \multicolumn{3}{|c|}{ Epileptic } & \multicolumn{3}{|c|}{ Control } \\
\hline & Ambulant & Non-ambulant & $\begin{array}{c}\text { Total } \\
\text { epileptics }\end{array}$ & Ambulant & Non-ambulant & $\begin{array}{c}\text { Total } \\
\text { controls }\end{array}$ \\
\hline \multicolumn{7}{|c|}{ Glucaric acid $\mu \mathrm{mol} / 1$ urine } \\
\hline $\begin{array}{l}\text { children } \\
\text { adults } \\
\text { Glucaric acid }\end{array}$ & $\begin{array}{r}7 \cdot 7^{*} \pm 1 \cdot 3 \\
4 \cdot 5 \pm 0 \cdot 7 \\
001 / 24 \mathrm{hr}\end{array}$ & $\begin{array}{r}5 \cdot 9 \ddagger \pm 0 \cdot 6 \\
5 \cdot 1 \pm 1 \cdot 2\end{array}$ & $\begin{array}{l}6 \cdot 8 \ddagger \pm 0 \cdot 7 \\
4 \cdot 8 \dagger \pm 0.7\end{array}$ & $\begin{array}{l}3 \cdot 5 \pm 0.5 \\
2 \cdot 7 \pm 0.5\end{array}$ & $\begin{array}{l}2 \cdot 5 \pm 0 \cdot 2 \\
2 \cdot 3 \pm 0 \cdot 6\end{array}$ & $\begin{array}{l}3 \cdot 0 \pm 0 \cdot 3 \\
2 \cdot 5 \pm 0 \cdot 4\end{array}$ \\
\hline \multicolumn{7}{|c|}{ Glucaric acid $\mu \mathrm{mol} / \mathrm{gm}$ creatinine } \\
\hline $\begin{array}{l}\text { children } \\
\text { adults }\end{array}$ & $\begin{array}{r}7 \cdot 8 \pm 2 \cdot 2 \\
12 \cdot 7^{*} \pm 4 \cdot 1 \\
\end{array}$ & $\begin{array}{l}8 \cdot 1 \dagger \pm 1 \cdot 3 \\
11 \cdot 1 \pm 3 \cdot 3 \\
\end{array}$ & $\begin{array}{r}8 \cdot 0 \dagger \pm 1 \cdot 2 \\
11 \cdot 9 \ddagger \pm 2 \cdot 5 \\
\end{array}$ & $\begin{array}{l}4 \cdot 2 \pm 1 \cdot 1 \\
3 \cdot 0 \pm 0 \cdot 5 \\
\end{array}$ & $\begin{array}{l}2 \cdot 8 \pm 0.5 \\
3.0 \pm 0.7 \\
\end{array}$ & $\begin{array}{l}3 \cdot 5 \pm 0.6 \\
3 \cdot 0 \pm 0.4 \\
\end{array}$ \\
\hline
\end{tabular}

Significant difference from corresponding control value, $* P<0.05 ; \dagger P<0.01 ; \ddagger P<0.001$. 
were, as anticipated, very variable, there was a trend towards lower urine creatinine levels in the epileptic subjects, but this reached levels of statistical significance only when the 24-hr urinary creatinine excretion was estimated. The $24-\mathrm{hr}$ excretion of creatinine in the epileptic adults was $0.84 \pm 0.11 \mathrm{~g}$ as compared with $1.34 \pm 0.13 \mathrm{~g}$ in the adult controls $(P<0.01)$. In both epileptics and controls the urine creatinine, and also the body weight, tended to be lower in non-ambulant than in ambulant subjects, but in neither case were the differences statistically significant. The urinary creatinine excretion was $0.9 \pm 0.2$ $\mathrm{g} / 24 \mathrm{hr}$ in the non-ambulant adults, and $1 \cdot 2 \pm 0 \cdot 1$ $\mathrm{g} / 24 \mathrm{hr}$ in the ambulant adults.

The bone densitometry measurements were in general similar in epileptics and controls (Table 3), the low figure recorded in the adult control nonambulant group being due to the presence of a single extremely low reading of $0.37 \mathrm{~g} / \mathrm{cm}(-71 \%$ of predicted norm) in a grossly retarded young male, immobile since infancy. In all the children, and in twenty of the twenty-four adults, the figures recorded were lower than the predicted norm for a North American population (Cameron, 1970). In the children, bone densitometry readings were significantly lower in the non-ambulant as compared with the ambulant, whether epileptic or control (Table 3). This difference between ambulant and non-ambulant subjects did not, however, appear to hold for adults. The repeat bone densitometry estimations in the sixteen children treated with vitamin $D$ supplements over a 6-month period showed no significant change, and this study is still in progress.

No radiological signs of rickets or osteomalacia were found in any of the subjects studied, but radiological evidence of bone thinning was reported in the two adults with the lowest bone mineral content as measured by densitometry, one of whom was a non-ambulant epileptic and the other a nonambulant control.

The average daily dietary intake of vitamin $D$ in the children was assessed as $237 \mathrm{iu}$, as compared with the recommended daily allowance of 400 iu (Nelson, 1969), and 95 iu in the adults, as compared with their estimated daily requirement of 75 iu (Dent and Smith, 1969).

\section{Discussion}

Although between 15 and $50 \%$ of patients on anticonvulsant drugs are said to show evidence of secondary vitamin D-deficiency (Nordin, 1973), no such changes have been clearly demonstrated in this study. This may be surprising since the subjects in this investigation had high and prolonged anticonvulsant dosage, and previous surveys of patients in institutions have shown a positive correlation between the serum biochemical abnormalities and the drug dosage, or duration of treatment (Richens and Rowe, 1970). The anti-convulsant drugs, however, appear to differ in their potential for the production of vitamin D-deficiency. The least toxic in this respect is phenobarbitone, a drug which was taken by most of our epileptic patients, and the most toxic pheneturide (Nordin, 1973), which was not taken by any of our patients.

The principal postulated mechanism for production of vitamin D-deficiency by anticonvulsant drugs is accelerated breakdown of vitamin $D$ by drug-induced hepatic enzyme induction (Dent et al., 1970). It has recently been suggested that it is possible to assess liver microsomal enzyme activity quantitatively by measuring the urinary excretion of Dglucaric acid (Hunter et al., 1971). The significantly higher urinary excretion of D-glucaric acid in our epileptic patients as compared with controls could be taken as evidence of hepatic enzyme induction, and consequently of accelerated breakdown of vitamin $D$, but presumably to a degree insufficient to result in significant biochemical or clinical vitamin D-deficiency. Our observation that vitamin D supplementation in these children produced no increase in bone densitometry values is in keeping with this conclusion. A similar study of vitamin D administration in epileptics thought to have vitamin D-deficiency has been reported to show a significant increase in bone mineral within 2 months (Christiansen, Kristensen and Rødbro, 1972). The lower

TABLE 3. Bone densitometry values (mean and s.e. mean.)

\begin{tabular}{|c|c|c|c|c|c|c|}
\hline & \multicolumn{3}{|c|}{ Ambulant } & \multicolumn{3}{|c|}{ Non-Ambulant } \\
\hline & Epileptic & Control & $\begin{array}{c}\text { Total } \\
\text { ambulant }\end{array}$ & Epileptic & Control & $\begin{array}{c}\text { Total } \\
\text { non-ambulant }\end{array}$ \\
\hline \multicolumn{7}{|c|}{ Bone mineral $\mathrm{g} / \mathrm{cm}$} \\
\hline $\begin{array}{l}\text { children } \\
\text { adults }\end{array}$ & $\begin{array}{l}0.63 \pm 0.09 \\
0.99 \pm 0.08\end{array}$ & $\begin{array}{l}0.63 \pm 0.05 \\
0.94 \pm 0.12\end{array}$ & $\begin{array}{l}0.63^{*} \pm 0.05 \\
0.97 \pm 0.07\end{array}$ & $\begin{array}{l}0.43 \pm 0.05 \\
1.06 \pm 0.11\end{array}$ & $\begin{array}{l}0.47 \pm 0.08 \\
0.76 \pm 0.11\end{array}$ & $\begin{array}{l}0.45 \pm 0.05 \\
0.91 \pm 0.09\end{array}$ \\
\hline \multicolumn{7}{|c|}{ Bone mineral percentage deviation from norm } \\
\hline $\begin{array}{l}\text { children } \\
\text { adults }\end{array}$ & $\begin{array}{l}-24 \pm 7 \\
-17 \pm 7\end{array}$ & $\begin{array}{l}-26 \pm 6 \\
-21 \pm 6\end{array}$ & $\begin{array}{r}-25 \dagger \pm 5 \\
-19 \pm 4\end{array}$ & $\begin{aligned} &-43 \pm 2 \\
&-6 \pm 10\end{aligned}$ & $\begin{array}{l}-47 \pm 9 \\
-35 \pm 8\end{array}$ & $\begin{array}{l}-45 \pm 4 \\
-20 \pm 7\end{array}$ \\
\hline
\end{tabular}


urinary creatinine excretion in epileptics, demonstrated in this study, is unexplained and requires further confirmation.

It is of interest that the three children with bone fractures, although epileptic, were all non-ambulant, and that two of these three children had normal serum biochemical findings at the time of their spontaneous fractures. The lower densitometry measurements in the non-ambulant children as compared with the ambulant suggest that osteoporosis rather than vitamin D-deficiency is the major bone problem in these severely handicapped children. The adults were physically less severely handicapped than the children, and the majority of the nonambulant group were not confined to bed but were able to stand with assistance. This may account for the absence of similar clear-cut differences in bone densitometry measurements between ambulant and non-ambulant groups of adults.

\section{Acknowledgments}

We thank Dr A. Cook for permission to study his patients, Dr A. F. Macdonald and Dr B. Gill for reporting the radiographs, and the nursing staff of both hospitals for their assistance.

\section{References}

CAMERon, J.R. (1970) Summary of data on the bone mineral of the radius in normals. Ref. no. COO-1422-41, University of Wisconsin, U.S..A.

Cameron, J.R. \& Sorenson, J. (1963) Measurement of bone mineral in vivo: an improved method. Science, 142, 230.

Christiansen, C., Kristensen, M. \& Rødbro, P. (1972) Latent osteomalacia in epileptic patients on anticonvulsants. British Medical Journal, iii, 738.

Dent, C.E. \& SMiтh, R. (1969) Nutritional osteomalacia. Quarterly Journal of Medicine, 38, 195.

Dent, C.E., Richens, A., Rowe, D.J.F. \& Stamp, T.C.B. (1970) Osteomalacia with long-term anticonvulsant therapy in epilepsy. British Medical Journal, iv, 69.

Hahn, T.J., Birge, S.J., ScharP, C.R. \& Avioli, L.V. (1972) Phenobarbital-induced alterations in vitamin $D$ metabolism. Journal of Clinical Investigation, 51, 741.

Hunter, J., Maxwell, J.D., Stewart, D.A., Parsons, V. \& Williams, R. (1971) Altered calcium metabolism in epileptic children on anticonvulsants. British Medical Journal, iv, 202.

Nelson, W.E. (1969) In: Textbook of Paediatrics, 9th edition, p. 136. Philadelphia.

Nordin, B.E.C. (1973) In: Metabolic Bone and Stone Disease, p. 73. Churchill Livingstone: Edinburgh.

Richens, A. \& Rowe, D.J.F. (1970) Disturbance of calcium metabolism by anticonvulsant drugs. British Medical Journal, iv, 73. 